\title{
Comparison of Media Literacy Education Between Chinese and Western Students
}

\author{
Zhao Han ${ }^{1, *}$ \\ ${ }^{1}$ College of Communication Art, Chongqing University of Posts and Telecommunications, Chongqing, China,400065 \\ *Corresponding author. Email:1165712320@qq.com
}

\begin{abstract}
In an era of information explosion, it is very necessary for students to learn how to distinguish information and spread information correctly, because they are in a stage of value formation, which shows the importance of media literacy education. Media literacy education in western countries developed earlier. Through the comparison of media literacy education between China and the west, we can not only understand the development and impact of Western media literacy education, so as to learn from experience, but also find a series of problems existing in China's current student media literacy education, such as limited school popularity and student recognition, and explore some feasible measures. Among them, the teaching form and development status of Western media literacy education is very worthy of China's reference and research. China's media literacy education is not popular in schools at all levels, and the recognition of students needs to be strengthened, resulting in the slow development of China's current media literacy education. China's media literacy education needs to pay more attention to the student-centered main role, use the network influence to publicize and educate students, improve their own literacy and strengthen social stability.
\end{abstract}

Keywords: Media Literacy Education, Information dissemination, Network media

\section{INTRODUCTION}

It is an information society. Under the background of Internet big data, people are not only the receiver of information, but also the disseminator of information. In the face of diversified information, how to conduct dialectical screening and self-thinking mostly depends on personal media literacy, so media literacy education is particularly important in modern society. Media literacy education in western countries began to appear as early as the 1930s, and through years of exploration and research, their media literacy education has developed more mature. Compared with western countries, there is a huge gap in the field of media literacy education in China until now. Chinese students lack the concept of media literacy. Therefore, how to learn from the more successful media literacy education in western countries is particularly important. This research will use the literature research method and comparative research method. In this paper, the argument will start from the development of media literacy education in western countries, and current situation and problems of media literacy education in China. At last, the research will give the optimization measures of media literacy education in China.

\section{THE DEVELOPMENT OF MEDIA LITERACY EDUCATION IN WESTERN COUNTRIES}

\subsection{Teaching Forms of Western Media Literacy Education}

The teaching forms of media literacy education in western countries are different. Some are described separately as courses, while others are integrated into disciplines. Primary school education in Ontario, Canada is to set media literacy as a course for independent learning. In the media literacy curriculum of grades 9-12, media literacy education is integrated with Chinese, history, music and other courses[1].This teaching form could help teenagers master two knowledge through one course and have a better understanding of media literacy. The British media literacy covers all aspects from primary school to university. The media literacy education curriculum is carried out with diversity as the central word, and also sets up media literacy courses in the secondary academic level examination to increase the attention of students.[2] 


\subsection{Development Status of Media Literacy Education in the West}

Western media literacy education has been relatively mature since the 1930s.Both the people and the government attach great importance to the establishment and innovative optimization of media literacy education. Many governments have promulgated laws related to media literacy communication, especially in the education of students, such as the education law promulgated by Sweden, which clearly stipulates that school education should cultivate the ability of children and students to obtain media literacy education equally, so as to improve the level of social-cultural literacy and the degree of democracy and fairness.[3] In Finland and Ireland, in addition to official school education, there are a large number of non-governmental organizations to publicize and promote media literacy, so that social people of all ages can get educational opportunities and participate in it. On the whole, Western media literacy education can enable students and social people to spontaneously pay attention to and learn, which shows that the policies and publicity of the government and schools are very successful, and is of great benefit to the environmental security of the whole society and the improvement of people's independent thinking ability.[4]

\subsection{The Role of Western Media Literacy Education for Students}

Firstly, ultivation of discrimination information accuracy. The high implementation of Western media literacy education can educate students on how to distinguish information and have their own judgment ability in the era of highly developed network media, so as not to become a tool for the dissemination of some false news, which not only absorbs wrong views, but also has a negative impact on the society. Sweden's media literacy education emphasizes that students should cultivate this ability, which can not only improve their self-awareness, but also strengthen their national identity and ensure political correctness. Furthermore, the cultivation of professional knowledge of modern media. Finland's "media literacy week" is to impart professional knowledge related to network security to the public. [3] The network is an indispensable medium for students to obtain knowledge easily, whether in study or life. How to use it reasonably and safely needs to be imparted by professionals, This skill helps students avoid some dangerous and untrue information in the search and browsing stage.

\section{CURRENT SITUATION AND PROBLEMS OF MEDIA LITERACY EDUCATION IN CHINA}

\subsection{Current Situation of Media Literacy Education in China}

China's media literacy education developed late and began to study at the end of the 20th century. In recent years, with the development of science and technology and the Internet, the government and educators realized the importance of media literacy education for people's cognition and social stability, and gradually promulgated some policies. The first relevant content about media literacy education in China came from the study and translation of foreign media literacy education by educators, So as to explore an executable development road belonging to China. At present, China's media literacy education has been supported by a large number of government funds. Media literacy frequently appears in the guidelines of China Social Science Fund projects, and leaders of the education system are trained and studied on media literacy, so as to take the lead. [5]

\subsection{The School Popularity of Media Literacy Education in China is not High}

China's media literacy education implements a top-down model, from colleges and universities to primary and secondary schools. Colleges and universities first add relevant courses. After research, the model will continue to be implemented in primary and secondary schools after it is more mature. However, the number of media literacy education courses in Colleges and universities is not large, and few professional teachers are teaching this course in Colleges and universities, resulting in the low popularity of media literacy courses in Colleges and universities in many provinces and cities. The problem is even more serious in primary and secondary schools. Many schools lack relevant teachers, and due to the pressure of entering a higher school, the school does not set up too many courses, resulting in the lack of sustainable teaching of media literacy education in the key stage of students' forming values.

\subsection{The Student Recognition of Media Literacy Education in China Needs to be Strengthened}

Chinese students have limited knowledge of media literacy, which will directly lead to low recognition. As students, the most important transmission of their views comes from school education and family education. The number of media literacy education courses in China is limited. Even if it is integrated into some disciplines, it accounts for a small proportion. Because of China's large population base and fierce enrollment competition, 
examination course scores are still important in primary and secondary school education, As a result, students do not have a certain understanding and attention to media literacy when they are young. If analyzed from the part of family education, the popularity of media literacy education is even less, because in the era of their parents, China did not have the awareness of media literacy education, or they lacked such perspective at the stage of just beginning research, The dual neglect of media literacy by schools and parents leads to the low recognition of modern students for media literacy education.

\section{OPTIMIZATION MEASURES OF MEDIA LITERACY EDUCATION IN CHINA}

\subsection{It can be used as a Reference for Western Media Literacy Education}

Media literacy education in western countries has a lot of development experience which could be used for reference. First of all, Western governments promulgated many mandatory measures and carried out a lot of publicity from official channels. The proportion of mandatory media literacy courses in school education can be used for reference by the Chinese government and publicized in all aspects of society; secondly, many non-governmental organizations in western countries spontaneously promote media literacy education. Social organization personnel can directly publicize and explain with the people. As a country with a large population base, the formation of a high number of social organizations can play a very important role in the popularization of media literacy education; Finally, western countries attach great importance to the renewal of the concept of media literacy. [6]Only by keeping pace with the times can they understand the current hot spots and people's thoughts. After investigation and understanding, the policies and opinions promoted can have a more sense of identity and be deeply rooted in the hearts of the people.

\subsection{In Line with the National Education Scene}

In addition to learning from foreign experience, media literacy education also needs to conform to its own culture and national conditions. Compared with European and American countries, the number of students in China is too large, so the investment of professional teachers is a big problem. China should be funded by the government to train batch after batch of professional teachers to teach in schools at all levels. Chinese students have great academic competition. Therefore, how to carry out media literacy education without affecting students' performance and discipline pressure is still a problem that the Chinese government and education professionals need to consider.

\subsection{Using Network Influence to Strengthen the Main Role of Students}

The main proportion of Chinese people who surf the Internet is the post-90s, and most of them are students. It can be seen that students love and rely on the Internet. Therefore, the state needs to grasp this feature, start from students' concerns and use network media to publicize media literacy education, so that it is easier to be seen by students and deepen their influence. The government can also cooperate with bloggers who are more concerned about the student group. Through their publicity, when students see the output of their idols, they can more easily cause point of view recognition, so as to achieve twice the result with half the effort.

\section{CONCLUSION}

Generally speaking, government has not issued a large number of mandatory policies like western countries. It is necessary to fulfill such policy requirements from both voluntary and forced perspectives, otherwise, it will be punished, In this way, the compliance from top to bottom will imperceptibly promote the status of media literacy education and strengthen its recognition in people's psychology. The development of China's media literacy education draws on the skills of Western media literacy development, but it is not limited to reference. It is necessary to explore a nationalization road suitable for students' Education in our own country, innovate on the basis of reference, and explore some methods around students, Pay attention to students' subjectivity. In the future research on media literacy education, we need to strengthen our efforts in the primary and secondary school sector, instill the relevant ideas of media literacy and plant seeds at the beginning of the formation of students' learning knowledge and values, which will present a multiplier effect, and make China's students' media literacy education develop and mature more quickly and effectively.

\section{REFERENCES}

[1] Zhao Dongna.Curriculum analysis of media literacy education in secondary schools in Ontario, Canada[J].Journal of World education ,2013,26(18):52-54.

[2] Liu Xiaomin.Research on media literacy education in American primary and secondary schools [D]. Tutor:Zhang Guixin.Northeast Normal University,2012,05.

[3] You Yi. Research on foreign media literacy education -- a comparative analysis based on the three EU countries[J].Science and technology communication,2021,13(07):93-96. 
[4] National Association for Media Literacy Education. The Core Principles of Media Literacy Education[EB/OL].https://namle.net/publications/c ore- principles/.

[5] Zhang Kai, Ding Feisi. Playback and Prospect: 20 years of media literacy development in China[J]. Journalism and writing,2020,(08):5-12.

[6] Gu shengran,Wei Maolin.Review of media literacy research at home and abroad[J].Journal of southwestpetroleumuniversity2019,21(04):110-116 